\title{
Études/Inuit/Studies
}

\section{HART, Eliza J, 2001 Reindeer Days Remembered, Inuvik, Inuvialuit Cultural Resource Centre, 112 pages.}

\section{William Schneider}

Volume 28, numéro 1, 2004

Art et représentation

Art and representation

URI : https://id.erudit.org/iderudit/012654ar

DOI : https://doi.org/10.7202/012654ar

Aller au sommaire du numéro

\section{Éditeur(s)}

Association Inuksiutiit Katimajiit Inc.

ISSN

0701-1008 (imprimé)

1708-5268 (numérique)

Découvrir la revue

Citer ce compte rendu

Schneider, W. (2004). Compte rendu de [HART, Eliza J, 2001 Reindeer Days

Remembered, Inuvik, Inuvialuit Cultural Resource Centre, 112 pages.]

Études/Inuit/Studies, 28(1), 201-202. https://doi.org/10.7202/012654ar d'utilisation que vous pouvez consulter en ligne.

https://apropos.erudit.org/fr/usagers/politique-dutilisation/ 
the profound injustice its existence is predicated upon. One person's inclusive nationality is another person's appropriating, totalizing power.

\author{
Peter Kulchyski \\ Department of Native Studies \\ University of Manitoba \\ Winnipeg, Manitoba \\ Canada, R3T 5V5 \\ kulchysk@ms.umanitoba.ca
}

HART, Eliza J

2001 Reindeer Days Remembered, Inuvik, Inuvialuit Cultural Resource Centre, 112 pages.

Reindeer Days Remembered is a contribution to the growing literature sponsored by First Nations about their histories and cultures. Written primarily for members of the local cultural group, it features their observations about their activities in the industry. That said, the book has appeal beyond local audiences to those interested in Mackenzie Delta/Beaufort Sea history. The oral history quotes, the historic and contemporary photographs, and the clearly organized charts and graphs personalize the elders' story.

As the title suggest, this is a book about the herders' recollections of herding between the years 1935-1964. Interviews were done in 1991, 1992, and 2001 by the Inuvialuit Cultural Resources Centre with additional support from Northern Oil and Gas Action Program and Prince of Wales Northern Heritage Centre. Additional support was provided by the Polar Continental Shelf Project and the Inuvik Research Centre (now the Aurora Research Institute). Part of the documentation by the elders was recorded by the Inuvialuit Communication Society. They produced a video for their weekly program, "Tamapta."

In Reindeer Days Remembered, we learn that reindeer were introduced to the Delta because of the scarcity of caribou and that the herd came from Alaska on a drive that began in 1929 and took five years. The book chronicles the stress of herding, the hard work, and the isolation that herders and their families experienced. "The lack of success of the Native herds showed that herding was not a stable or predictable way to make a living. It was too isolating and presented too many hardships" (p. 94). Despite this pronouncement, and after years of management by Canadian Fish and Wildlife Service, the herd was sold to William Nasagaluak in 1978 and he maintained it.

Students of reindeer herding history in Alaska will find this book of interest for multiple reasons. The "story" of the five-year trek from Alaska is one that is known and told in Alaska. The theme of isolation and herding resonates in an all too familiar way with the recollections of Alaskan herders. The period of recollections recorded here ends in the early 1960s and snowmachines were introduced to northern communities in the mid 1960s. We know from the Alaskan experience, and the 
Scandinavians, that the machines had a major impact easing some of the challenges of driving reindeer, hunting down predators, and they provided quick access from villages to reindeer camps, thereby permitting herders to operate from villages as opposed to remote camps. They have also created their share of problems, not the least being the cost of maintaining and fueling them. Unfortunately, the experiences of herders recorded in this study predated snowmachines. It would be of interest to know how the machines changed herding in Northern Canada. Other points of common interest concern management of the herds and herd size fluctuations. When the herds reached Canada, they adapted a "close herding" policy (whereby herds were watched constantly by herd owners). This is in contrast to the Alaskans who had begun with a "close herding" management but switched in 1920 to "collective herding" (where herds from village areas were watched by hired herders). The Canadians switched to open herding in 1968 under Fish and Wildlife Service Management. Another interesting comparison is the rise and decline of the herds. The Alaskan herds experienced drastic declines in the 1930s and 40s and revitalization in the 1960s and post 60s period, an increase that continued until the recent massive influx of caribou. In Reindeer Days Remembered we learn that for the Mackenzie Delta herds, there was considerable variation in the years 1935-1960s but no sign of the devastating lows experienced in Alaska.

While students of the reindeer industry will find the comparisons of interest, the purpose of Reindeer Days Remembered is not primarily to induce comparison; it is to highlight the experiences of Inuvialuit herders in their region. It is to share the herders' recollections with their children and grandchildren who may never experience that way of life. Thanks to this book, now they can imagine and appreciate their elders' life a little bit more.

William Schneider Alaska and Polar Regions Department Elmer Rasmuson Library P.O. Box 756808 University of Alaska Fairbanks Fairbanks, Alaska 99775-6808, USA ffwss@uaf.edu

\section{NASBY, Judith \\ 2002 Irene Avaalaaqiaq: Myth and Reality, Montreal and Kingston, McGill- Queen's University Press, 128 pages.}

Irene Avaalaaqiaq: Myth and Reality by Judith Nasby is about the life and art of Baker Lake artist Irene Avaalaaqiaq. This book combines the artist's life history with historical accounts by ethnologists. Twenty-eight art works including wall hangings, prints and colour pencil drawings are presented with the author's interpretations.

Baker Lake artists are well-known for their prints, sculpture and wall hangings and several catalogues featuring Baker Lake art have been published. Biographies or retrospectives about Baker Lake artists have been written about Jessie Oonark 